\title{
Vlasta Švoger
}

(Hrvatski institut za povijest, Zagreb)

\section{MIJAT STOJANOVIĆ - OD „MAGAREĆE KLUPE“ DO ISTAKNUTOG PEDAGOGA I PUČKOG PISCA 19. STOLJEĆA}

UDK 37.01:32 Stojanović, M.

DOI 10.22586/ss.21.1.8

Izvorni znanstveni rad

Primljeno: 22. 12. 2020.

\begin{abstract}
$\mathrm{U} \mathrm{radu}^{1}$ će se analizirati javno djelovanje Mijata Stojanovića (1818.-1881.) na političkom, pedagoškom i publicističkom polju. Bio je jedan od najistaknutijih hrvatskih pučkih pisaca, učitelja i pedagoga u 19. stoljeću. Znanja stečena cjeloživotnim samoobrazovanjem prezentirao je u učionici, na stručnim skupovima učitelja, u knjigama namijenjenima puku, školskim udžbenicima i u brojnim člancima u političkim listovima i stručnim časopisima. U njima je pisao o ulozi škola u društvu, raznim pedagoškim pitanjima, praktičnim savjetima o gospodarstvu i političkim temama. Preveo je i nekoliko pedagoških priručnika istaknutih stranih pedagoga. Svojim javnim djelovanjem pridonio je transferu ideja i znanja iz drugih europskih zemalja i njihovoj recepciji u Hrvatskoj na političkom i pedagoškom polju.
\end{abstract}

Ključne riječi: Mijat Stojanović, povijest školstva, transfer ideja i znanja, pedagoško djelovanje, publicističko djelovanje, 19. stoljeće, Hrvatska

\section{UVOD}

Mijat Stojanović bio je iznimno zanimljiva osoba. Stjecajem okolnosti stekao je vrlo skromno formalno obrazovanje, pa je ponajprije zahvaljujući izvanrednoj samodisciplini, motiviranosti i samoobrazovanju postao jedan od najistaknutijih hrvatskih pučkih pisaca i pedagoga u 19. stoljeću. U političkom životu bio je najaktivniji tijekom revolucionarnih previranja 1848.-

\footnotetext{
${ }^{1}$ Istraživanje je provedeno u sklopu projekta „Europski korijeni moderne Hrvatske: transfer ideja na političkom i kulturnom polju u 18. i 19. stoljeću“" (EuKor), IP-2018-01-2539, koji financira Hrvatska zaklada za znanost.
} 
49., kada je bio i izabrani zastupnik u Hrvatskom saboru. U radu će se ukratko prikazati Stojanovićev životni i profesionalni put, a potom će se analizirati njegovo javno djelovanje na političkom, publicističkom i pedagoškom polju. Bio je vrlo plodan pisac. Objavio je velik broj članaka u političkim listovima i stručnim pedagoškim časopisima, napisao je veći broj knjiga namijenjenih puku i školskih udžbenika te preveo nekoliko pedagoških priručnika istaknutih stranih pedagoga. U njegovoj ostavštini u Hrvatskom školskom muzeju sačuvano je desetak djela u rukopisu.

\section{MIJAT STOJANOVIĆ (1818.-1881.) - ŽIVOTNI PUT OD „MAGAREĆE KLUPE“ DO UGLEDNOG UČITELJA, PEDAGOGA I PUČKOG PISCA U HRVATSKOJ 19. STOLJEĆA}

Mijat Stojanović ${ }^{2}$ rođen je u seljačkoj obitelji 26. rujna 1818. godine u Babinoj Gredi, selu koje je tada bilo dijelom Slavonske vojne krajine. U školu je krenuo tek u desetoj godini, a njegovo formalno obrazovanje obuhvaćalo je samo dvogodišnje školovanje u njemačkoj trivijalnoj školi u rodnome mjestu. Isprva je imao poteškoća u učenju, zbog čega ga je učitelj često kažnjavao šibanjem. Neadekvatna odgojna metoda fizičkog kažnjavanja, u prvoj polovici 19. stoljeća uobičajena u Hrvatskoj, kod Mijata je izazvala strah od učitelja, pa dječak nije mogao pokazati stečeno znanje. Zbog toga je kao najgori učenik u razredu morao sjediti u „magarećoj klupi“. ${ }^{3}$ Ipak je nakon nekog

${ }^{2}$ Od novije literature o Mijatu Stojanoviću usp. Mihajlo Ogrizović, „Mijat Stojanović“, u: Sto godina Hrvatskog pedagoško-književnog zbora i učiteljstva u Hrvatskoj 1871-1971, ur. Dragutin Franković, Mihajlo Ogrizović i Dragutin Pazman (Zagreb, 1971), 369-402; Mihajlo Ogrizović, Likovi istaknutih pedagoga II. Ljudevit Modec, Mijat Stojanović, Stjepan Basariček (Zagreb, 1980), 85-141; Krunoslav Tkalac, „Rad Mijata Stojanovića kao školnika“, u: Krunoslav Tkalac, Školstvo Slavonije u 18. i 19. stoljeću - Mijat Stojanović 1818.-1881. (Županja, 1973), 71-91; Krunoslav Tkalac, „Život i rad pučkog pisca Mijata Stojanovića“, u: Tkalac, Školstvo Slavonije u 18. i 19. stoljeću, 110-132; Marko Landeka, „Život i rad Mijata Stojanovića“, u: Istaknuti Babogreci I., ur. Zlatko Virc i Ilija Babić (Vinkovci, 1999), 25-43; Marko Landeka, „Prilog pedagoga Mijata Stojanovića hrvatskoj usmenoj književnosti“, u: Četvrti znanstveni sabor Slavonije i Baranje. Zbornik radova (Osijek, 1984), 517-523; Omerka Žigić, „Mijat Stojanović, hrvatski pedagog, etnograf i pučki pisac", u: Mijat Stojanović, Slike iz domaćeg života slavonskog naroda i iz prirode s dodatkom Slavonske pučke sigre, prir. Omerka Žigić (Vinkovci, 1994), 183-189; Dinko Župan, „Brodska Posavina prve polovice 18. stoljeća iz vizure historiografske fikcije Mijata Stojanovića“, Prilozi za povijest Broda i okolice 1, ur. Marija Karbić (Slavonski Brod, 2013), 19-33, Dinko Župan, „Stojanovićeve 'Zgode i nezgode'“, u: Mijat Stojanović, Sgode i nesgode moga života, prir. Dinko Župan, Stanko Andrić i Damir Matanović (Slavonski Brod, 2015), IX-XXII.

${ }^{3} \mathrm{O}$ tome je u svojoj autobiografiji zapisao: „Učitelj me je svojom strogošću mahom prvih danah tako poplašio i što se veli u tikvu stjerao, zadao mi strah u kosti, da kad sam ga samo vidio pred sobom, već sam štrepio, i štogod bi me kad zapitao, na ništa mu nisam znao odgovoriti (...) Štogod me je g. moj učitelj dao više šibati i štogod me je više grdio po tadanjem neshodnom, nespretnom i nevaljalom načinu podučavanja, to sam je bivao sve tuplji i gluplji. 
vremena uspio svladati strah od učitelja i počeo napredovati u učenju. Njegov drugi učitelj je primjenom poticajnih odgojnih metoda u dječaka uspio razviti interes i motivaciju za učenje i Mijat je ubrzo postao najboljim učenikom u razredu. Učitelj ga je predložio za nastavak obrazovanja u glavnoj školi u Vinkovcima, ali Mijatov otac na to nije pristao jer je obitelj trebala dječakovu pomoć u svakodnevnim poslovima. Ipak, na nagovor učitelja Filipovića, kojemu je trebala pomoć u školi nakon što je u školskoj godini 1831/32. u Vojnoj krajini uvedeno obvezno školovanje za djecu oba spola, otac je dopustio da Mijat postane pomoćnik učitelja u Babinoj Gredi. Potom je radio kao početni pomoćni učitelj u Šamcu. Tijekom prvih godina učiteljske službe je, prema vlastitim riječima, imao vrlo skromno znanje, koje je nadopunjavao upornim i kontinuiranim samoobrazovanjem, pa je noću učio gradivo koje je trebao podučavati svoje učenike. ${ }^{4}$ Godine 1834 . položio je prvi ispit iz pedagogije, a iduće je godine pohađao tečaj za učitelje u Vinkovcima. Nakon što je položio učiteljski ispit Stojanović je radio kao pomoćni učitelj u Velikoj Kopanici, Brodu na Savi, Otoku, Županji i ponovno u Velikoj Kopanici. Deset godina nakon što je položio prvi stručni ispit postao je učiteljem u svom rodnom selu Babinoj Gredi. Nakon što je položio stručni ispit u Mitrovici 1851. godine, za koji se zbog bolesti supruge morao samostalno pripremati, stekao je kvalifikacije za nadučitelja i premješten je u Srijemske Karlovce kao učitelj na glavnoj školi, a 1858. dobio je mjesto nadučitelja u glavnoj školi u Zemunu. U Zemunu je kao suplent (namjesni učitelj) na realci predavao njemački jezik, opću povijest, zemljopis i krasopis, a kasnije srpski jezik. Česti premještaji učitelja u 19. stoljeću bili su uobičajena praksa. Ipak, u Zemunu je Stojanović ostao trinaest godina i u gradu je kupio kuću, nadajući se da će tu dočekati mirovinu. Međutim, 1871. godine postavljen je za okružnog školskog nadzornika slunjskog područja sa sjedištem u Karlovcu. Dvije godine kasnije premješten je za okružnog školskog nadzornika u Ogulin, a već iduće godine imenovan je okružnim školskim nadzornikom u Gospiću, gdje je ostao do umirovljenja 1877. godine. Umirovljeničke dane proveo je u Zagrebu uz pojačan angažman u Hrvatskom pedagogijsko-književnom zboru, tada najvažnijoj pedagoškoj strukovnoj udruzi u Hrvatskoj. ${ }^{5}$

(...) Tek poslije njekako ugledam se ja u primjer dobrih učenikah, probudim se kao iza sna, pukne mi izmjedju očiuh, čvor se razrieši u glavi, ohrabrim se, počnem pozornije paziti i liepo odgovarati (...) Godine 1829. dobio sam po smrti moga prvoga učitelja, drugoga, g. Vinka Filipović, Kopaničanina. Sve je to pošlo samnom drugčije, na bolje, proveram i protiskam se do prve klupe, i skoro zatim budem premješćen u prvu klupu u školi nazivanu 'Ehrenbank' medju prve i najbolje učenike." Stojanović, Sgode i nesgode, 49-50.

${ }^{4}$ U autobiografiji o tome piše: „Dan, noć patio sam se. Po noći pripravljao sam se, kako ću valjano predavati u školi propisane predmete sve u njemačkom jeziku: čitanje, pisanje, računanje, slovnicu, vjeronauk itd." Stojanović, Sgode i nesgode, 56.

5 Župan, „Stojanovićeve 'Zgode i nezgode', XIX-XXII; Tkalac, „Rad Mijata Stojanovića kao školnika“, 71-91; Landeka, „Život i rad M. Stojanovića“, 29. 
Iz Stojanovićeve autobiografije saznajemo da je u procesu samoobrazovanja, koji je trajao do kraja njegova života, čitao pedagoška djela, beletristi$\mathrm{ku}$, znanstvenu literaturu o povijesti, zemljopisu i drugim znanostima, ponajprije na njemačkom jeziku, a manje na hrvatskom. Također je čitao domaće i inozemne novine i časopise. Na taj je način upoznao nove ideje i znanja iz pedagogije, humanističkih znanosti, ali i one na političkom, gospodarskom i književnom polju, formulirane u drugim europskim zemljama, ponajprije zapadnoeuropskim, o kojima je kritički promišljao i koje je kasnije zagovarao i popularizirao u svom političkom, publicističkom i pedagoškom djelovanju. Kasnije je samostalno naučio češki i slovenski jezik, pa je čitao literaturu i na tim jezicima.

Nakon 1848. godine i u Hrvatskoj se po uzoru na druge europske zemlje održavaju učiteljske skupštine koje su trebale poslužiti razmjeni iskustava između učitelja i artikuliranju važnih aktualnih pitanja vezanih za poboljšanje stanja u školstvu i unapređenje pedagoške struke. Stojanović je vrlo aktivno sudjelovao na trima općim skupštinama hrvatskih učitelja (Zagreb, kolovoz 1871., Petrinja, kolovoz 1874., Osijek, rujan 1878.), na skupštinama vojnokrajiških učitelja (Vinkovci, 1849., Petrinja, 1850., Gospić, rujan 1875.) te na nekoliko inozemnih učiteljskih skupština (III. opća skupština austrijskih učitelja u Grazu, kolovoz-rujan 1869., XIX. opća skupština njemačkih učitelja, Beč, lipanj 1870., na kojoj je govorio o obrazovanju djevojaka). ${ }^{6}$ Vrlo aktivno se angažirao na strukovnom organiziranju hrvatskih učitelja i učiteljica i bio je jedan od osnivača Hrvatskog pedagogijsko-književnog zbora, osnovanog 1871. godine, najvažnije pedagoške udruge u Hrvatskoj u 19. stoljeću (koja djeluje i danas). Od 1878. bio je knjižničar Zbora, a od 1879. do svoje smrti bio je njegov predsjednik. ${ }^{7}$

I nadređeni su cijenili profesionalni angažman Mijata Stojanovića. U prosincu 1868. godine iz Ministarstva rata iz Beča dobio je upit o tome kako podignuti kvalitetu pučkih škola u Vojnoj krajini, kako organizirati različite tipove pučkih škola za učenike oba spola i kakav bi trebao biti nastavni plan. Stojanović je na temelju vlastitog dugogodišnjeg iskustva opširno odgovorio na ta pitanja i odgovore poslao u Beč. U lipnju iduće godine u Petrovaradinu je sudjelovao na savjetovanju o budućem ustroju pučkih škola u Vojnoj krajini. Nakon povratka kući izradio je zakonske prijedloge o ustroju i djelovanju šestogodišnjih općinskih škola i četverogodišnjih državnih glavnih škola i poslao ih u Beč savjetniku za školstvo u Ministarstvu rata dr. Baltazaru Bogi-

${ }^{6}$ Tkalac, „Rad Mijata Stojanovića kao školnika“, 75, 82-90.

${ }^{7}$ Sto godina Hrvatskoga pedagoško-književnog zbora i učiteljstva u Hrvatskoj (1871-1971); Hrvoje Vrgoč, Sto dvadeset pet godina Hrvatskog pedagoško-književnog zbora: 1871-1996 (Zagreb, 1996); Nevio Šetić, „Sto četrdeset godina Hrvatskog pedagoško-književnog zbora“, Napredak (Zagreb) god. 152, br. 3-4 (listopada 2011), 353-372. 
šiću. ${ }^{8} \mathrm{U}$ autobiografskim zapisima ne navodi da je dobio bilo kakav odgovor iz Beča na svoje prijedloge.

Mijat Stojanović bio je vrlo aktivan na spisateljskom i pedagoškom planu do kraja života. Umro je 18. rujna 1881. u Zagrebu, a sahranjen je na Mirogoju.

\section{MIJAT STOJANOVIĆ - POLITIČAR, PUČKI PISAC I ETNOLOG}

Početak Stojanovićeva rada u hrvatskom školskom sustavu poklopio se s najintenzivnijom fazom odvijanja hrvatskog preporodnog pokreta, koja je obilježena izlaženjem Gajevih listova na hrvatskom jeziku. Bile su to Novine Horvatzke i Danicza Horvatzka, Slavonzka y Dalmatinzka, ${ }^{9}$ koje su počele izlaziti 1835. godine. Iz Stojanovićeve autobiografije saznajemo da je uz knjige na temelju kojih se pripremao za nastavu čitao i druge knjige i novine: „počeo sam čitati i druge knjige njemačke i hrvatsko-srbske, i naše novine i časopise, počeo sam pisati i sastavljati u našem jeziku pjesmice i člančiće o koječemu; počeo sam skupljati gradivo za onaj spis za mladež, što sam ga poslije izdao pod naslovom 'Uprave za dobro i kriepostno vladanje i njekoje poslovice za mladež' (u Osieku tiska Divald god. 1844.) [.,,] Koju god sam poučnu knjigu čitao vadio sam iz nje i izpisivao pokraćeno ono, što mi se je najviše dopadalo. Skupljao sam svakom zgodom i prilikom pučke fraze, poslovice i pučke pripoviedke. " ${ }^{10}$ Iz navedenog citata može se razabrati da je M. Stojanović kao mladi učitelj, uz knjige na njemačkom jeziku, čitao domaće novine i časopise, pod čim zasigurno podrazumijeva i Gajeve listove, ali i da je već tada počeo prikupljati građu za svoje knjige namijenjene puku.

Iz njegovih autobiografskih zapisa potječe i informacija o tome da je 1846. godine prvi put posjetio Zagreb i da je tom prigodom upoznao istaknute pripadnike preporodnog pokreta: Ljudevita Gaja, Dimitriju Demetera, Vjekoslava Babukića, Antuna Mažuranića, Jakova Užarevića, Dragutina Rakovca i Stanka Vraza, koji su ujedno bili i Gajevi bliski suradnici u izdavanju Novina i Danice. S njima je Stojanović uspostavio uspješnu suradnju, o čemu je zapisao: „Poznanstvo ovih vrlih narodnjakah i plemenitih naših rodoljubah biaše mi poslije od velike koristi u poslu književnom."11

\footnotetext{
${ }^{8}$ Stojanović, Sgode i nesgode, 160-161, 163.

${ }^{9}$ O izlaženju navedenih listova pod različitim nazivima i u različitim političkim uvjetima usp. Josip Horvat, Povijest novinstva Hrvatske 1771-1939., prir. Mirko Juraj Mataušić (Zagreb, 2003), 81-83, 88-107, 153-156, 109-113.

${ }^{10}$ Stojanović, Sgode i nesgode, 57. Iz autobiografskog zapisa vidljivo je da se Stojanović referira na 1836. godinu.

${ }^{11}$ Stojanović, Sgode i nesgode, 65.
} 
Do proljeća 1848. godine, odnosno do izbijanja revolucionarnih nemira u brojnim europskim zemljama i Habsburškoj Monarhiji, u političkom životu Hrvatske razvila se snažna polarizacija na narodnjake i tzv. mađarone. Narodnjaci su bili članovi i pristaše Narodne stranke, koja je zagovarala očuvanje municipalnih prava, ostvarenje široke autonomije Trojedne Kraljevine i uvođenje narodnog, odnosno hrvatskog jezika sa štokavskom osnovicom, koji su tada nazivali ilirskim, kao službenog u upravu, sudstvo i školstvo. Nasuprot njima, mađaroni, odnosno članovi i pristaše Horvatsko-vugerske stranke, bili su spremni na popuštanje pred mađarskim zahtjevima i branili su uporabu latinskog i horvatskog jezika, odnosno kajkavskog dijalekta. U takvim okolnostima Stojanović je podupirao politiku narodnjaka, o čemu je zapisao: „Košut Lajoš upali Madjarsku i proti naše trojednice. U Madjarskoj poče se pojavljivati republikanska težnja; učini se dar mar po Ugarskoj i Galiciji. Hrvati i Slavonci postadoše opozicijom proti Madjarom; postadoše stranke i u našoj postojbini za i proti težnjam madjarskim. Ja sam se držao stranke rodoljubah hrvatsko-slavonskih, našeg bana Jelačića i onih muževah, koji su bili za municipalna prava trojedne kraljevine i za obstanak cielokupnosti monarkije po smislu pragmatičke sanctie." ${ }^{12}$

U to vrijeme brzih izmjena važnih političkih događaja i među najširim narodnim slojevima, uključujući i nepismeno seljačko stanovništvo, pojačao se interes za (političkim) informacijama. U tome su važnu ulogu informatora, tumača, savjetnika i svojevrsnih političkih vođa imali obrazovani ljudi, u seoskim sredinama uglavnom učitelji i svećenici. O tome svjedoči i sljedeći Stojanovićev autobiografski zapis: „Buduć su moji seljani, s’ kojimi sam živio u ljubavi i prijateljstvu, imali većom stranom povjerenje u mene, te me često jatimice posjećali, pak sam jim često čitao sad gospodarski list zagrebački, sad novine narodne. Zato kad stigoše i u našu Posavinu slavonsku viesti, šta biva po svietu, šta se dogadja po carevini našoj; kako se sviet na sve strane koleba i buni; kako naši susjedi Madjari o tom rade, da svoju vlast, svoj jezik, svoju narodnost i kod nas, i medju nami razšire, kako bi postali naši gospodari, a mi njihove sluge; kad se pročuje, što rade braća Hrvati sa svietlim banom Jelačićem: počmu moji seljaci u velikom broju dolaziti k' meni, da jim čitam novine, da čuju, šta se radi po svietu i po domovini, da jih obučim, šta treba da i mi činimo u tom obćem metežu, kako da se ponašamo u tom kritičnom i opasnom vremenu prama caru, prama banu, prama susjedom Madjarom, koji onda računahu i slavonsku krajinu našu za svoju zemlju, a krajišnike za svoje podajnike. Licem na veliki petak, 21. travnja 1848. god. sastade se kod mene velik broj seljanah, i u kratko jih ja izviesti o svemu, što je i kako je, i rekoh, da nam ino neostaje, nego da budemo vierni svome caru, i da se složimo sa hrvatskom svojom braćom. ${ }^{\text {"13 }}$

\footnotetext{
12 Stojanović, Sgode i nesgode, 66.

${ }^{13}$ Stojanović, Sgode i nesgode, 66-67.
} 
Mijat Stojanović u to je vrijeme stekao vrlo velik ugled i utjecaj u sredini u kojoj je živio, o čemu svjedoči i činjenica da je izabran za jednog od četvorice zastupnika Brodske pukovnije u Hrvatskom saboru $1848 .{ }^{14} \mathrm{U}$ radu Sabora podupirao je zastupnike Vojne krajine koji su zahtijevali da se Vojna krajina sjedini s Trojednom Kraljevinom, a dok se to ne ostvari da se uklone tegobe krajišnika donošenjem tzv. „polakšica“. Zbog složene političke situacije u kojoj se Habsburška Monarhija tada nalazila (oružana pobuna u sjevernim talijanskim pokrajinama; Ugarska koja je nakon donošenja tzv. travanjskih zakona [liberalni ustavni zakoni koje je vladar sankcionirao 11. travnja 1848.] ostvarila personalnu uniju s ostatkom Monarhije) većina zastupnika Hrvatskog sabora nije prihvatila krajiške zahtjeve. ${ }^{15}$

Tijekom revolucionarnih godina 1848.-1849. Mijat Stojanović najintenzivnije se bavio politikom. Nakon prekida rada Hrvatskog sabora, početkom srpnja 1848. godine, na kasnijim izborima za Sabor više nije sudjelovao kao kandidat za zastupnika. Ipak, to ne znači da je bio pasivan u političkom smislu. Političku aktivnost iskazivao je pišući u onodobnim političkim listovima o problemima i mogućnostima razvoja hrvatskog školstva (o čemu će biti riječi kasnije), ali i o drugim tada aktualnim temama, ponajprije vezanima za ustavnost, politička prava i slobode stečene 1848. godine u europskim zemljama u kojima su izbili revolucionarni nemiri i u Habsburškoj Monarhiji. Na temelju kritičkog promišljanja o političkim idejama koje je upoznao čitajući stranu literaturu i novine i o mogućnosti njihove primjene u Hrvatskoj i Habsburškoj Monarhiji pisao je o glavnim obilježjima političkog sustava utemeljenog na ustavnosti i o ulozi političkih stranaka u ustavnoj monarhiji. ${ }^{16}$ Držao je nužnim očuvanje jedinstva Habsburške Monarhije, ali uz ostvarenje ravnopravnosti naroda koji u njoj žive. ${ }^{17}$ Pisao je o vrlo teškom

${ }^{14} \mathrm{O}$ političkom djelovanju M. Stojanovića tijekom revolucionarnih godina 1848.-1849. usp. Krunoslav Tkalac, „Politički rad Mijata Stojanovića 1848.-1850. Njegovi pogledi na važnije političke događaje do 1881. god.“, u: Tkalac, Školstvo Slavonije u 18. i 19. stoljeću, 110-132 i Stojanović, Sgode i nesgode, 67-75.

15 O Hrvatskom saboru 1848. usp. Nikša Stančić, „Hrvatski ‘dèržavni sabor’ 1848: na razmeđu epoha i sukobljenih legaliteta“, u: Hrvatski državni sabor 1848., sv. I., ur. Josip Kolanović (Zagreb, 2001), 29-63; Tomislav Markus, Hrvatski politički pokret 1848.-1849. godine. Ustanove, ideje, ciljevi, politička kultura (Zagreb, 2000), 113-164; Ivo Perić, Hrvatski državni sabor 1848.-2000. Prvi svezak: 1848.-1867. (Zagreb, 2000), 123-198; Hodimir Sirotković, „Jelačićev izborni red i najvažniji državnopravni akti Hrvatskog sabora 1848. godine“, u: 150. obljetnica hrvatskog pokreta iz 1848. Javni sastanak održan 5. lipnja 1998. Predavanja održana u Hrvatskoj akademiji znanosti i umjetnosti, sv. 72, ur. Andrija Kaštelan (Zagreb, 1998), 9-33.

${ }^{16}$ M. Stojanović, „O strankah u dèržavi i o pravu izbora starešinah“, Slavenski Jug (SJ) (Zagreb), god. 2, br. 46 (19. 4. 1849). Stojanovićevo autorstvo u bilješkama je označeno na način na koji je to učinjeno u izvorniku.

${ }^{17}$ Mijat Stojanović, „Nekoliko rěčih bratji Slavoncem“, Novine hèrvatsko-slavonsko-dalmatinske (NHSD) (Zagreb), god. 14, br. 65 (24. 6. 1848); Mijat Stojanović, „Teženje slavensko. O 
materijalnom, političkom i društvenom položaju naroda u Vojnoj krajini, za što je krivnju pripisivao stranoj, austrijskoj vladavini. ${ }^{18}$ Oštro je kritizirao međuvjerske sukobe katolika i pravoslavaca u južnoslavenskim pokrajinama i prikazivao teške posljedice nejedinstva uzrokovanog vjerskim razlikama ${ }^{19}$ te posljedice gospodarske nerazvijenosti i korumpiranih državnih službenika u Hrvatskoj..$^{20}$

Pisao je i o drugim temama. O povijesti Srijema napisao je nekoliko članaka objavljenih u časopisu Sriemski Hrvat. ${ }^{21} \mathrm{O}$ novim metodama obrade zemlje u poljoprivredi i o različitim otkrićima u prirodnim znanostima pisao je u časopisu Slavonac. ${ }^{22} \mathrm{Na}$ stranicama istog časopisa objavio je članke o nekim institucijama građanskog društva, koje se u Hrvatskoj počelo izgrađivati tijekom revolucionarnih godina 1848.-1849. ${ }^{23} \mathrm{U}$ časopisu Arkiv za povjestnicu jugoslavensku objavio je nekoliko članaka u kojima je predstavio različite hrvatske narodne običaje prigodom vjenčanja, žalovanja zbog smrti najbližih, prigodom proslave važnih vjerskih i pučkih blagdana te pučka vjerovanja u nadnaravna bića (vile, vukodlake itd.). ${ }^{24}$ Pisao je i o kulturno-povijesnim i prirodnim znamenitostima Srijema. ${ }^{25} \mathrm{U}$ istome časopisu razjasnio je etimologiju velikog broja toponima istočne Slavonije i Srijema, ${ }^{26}$ dok je u drugome članku na osnovi kritičke analize izvorne građe i literature domaćih

slobodi. O jednakosti.“, Prijatelj puka (PP) (Zagreb), god. 1, br. 5 (6. 9. 1848), br. 11 (18. 10. 1848) i br. 12 (1. 11. 1848).

${ }^{18}$ M. St., „Niešto o krajini“, SJ, god. 2, br. 27 (3. 3. 1849).

${ }^{19}$ M. St., „Iz Slavonie na zač. B. D. M.“, Narodne novine (NN) (Zagreb), god. 15, br. 216 (14. 12. 1849).

${ }^{20}$ M. St., „U Slavonii 25. listopada“, NN, god. 15, br. 181 (2. 11. 1849).

${ }^{21}$ Mijat Stojanović, „Sriemski Karlovci“, Sriemski Hrvat (Vukovar), god. 2, br. 8 (20. 2. 1879); M. St., „Iz poviesti Sriema“, Sriemski Hrvat, god. 2, br. 23 (5. 6. 1879).

${ }^{22}$ Mijat Stojanović, „Kućnik ili mali gospodar“, Slavonac (Požega), god. 1, br. 5 (20. 2. 1863), 73-75, br. 21 (31. 7. 1863), 329-332; br. 26 (20. 9. 1863), 411-415, br. 34 (10. 12. 1863), 538-542; Mijat Stojanović, „Iz naravoslovja za puk“, Slavonac, god. 1, br. 30 (31. 10. 1863), 475-479, br. 31 (10. 11. 1863), 488-492; Mijat Stojanović, „Nješto iz prirodo-zemljo- i zviezdoznanstva za puk", Slavonac, god. 2, br. 3 (31. 1. 1864), 42-47, br. 4 (10. 2. 1864), 59-60, br. 8 (20. 3. 1864), 124-126, br. 9 (31. 3. 1864), 140-142.

${ }^{23}$ Mijat Stojanović, „Nješto o domoljubu i rodoljubu“, Slavonac, god. 2, br. 10 (10. 4. 1864); „Seoski knez. Odlomci (ulomci). Iz dnevnika bivšega zastupnika na našemu saboru od god. 1848.“, Slavonac, god. 2, br. 20 (20. 7. 1864), 317-319; br. 21 (31. 7. 1864), 330-333; br. 22 (10. 8. 1864), 348-351; br. 23 (20. 8. 1864), 362-368.

${ }^{24}$ Mijat Stojanović, „Nešto o našoj pověstnici“, Arkiv za povjestnicu jugoslavensku (Arkiv), knj. 1 (Zagreb, 1851), 216-220; Mijat Stojanović, „Odgovor na pitanja“, Arkiv, knj. 2 (Zagreb, 1852), 344-403.

25 Mijat Stojanović, „Njekoje znamenitosti iz Sriema“, Arkiv, knj. 4 (Zagreb, 1857), 178-188.

${ }^{26}$ Mijat Stojanović, „Sitnice o postanju imena njekih gradovah, trgovištah i selah slavonskosriemskih; zatim biskupijah, župah itd.“, Arkiv, knj. 5 (Zagreb, 1859), 189-205. 
i stranih autora, ponajprije statističkog opisa Vojne krajine Karla Bernharda von Hietzingera, ${ }^{27}$ prikazao nastanak i ustroj Vojne krajine u povijesnom kontekstu. ${ }^{28}$

Stojanović je pisao i pripovijetke i pjesme za puk, skupljao je narodne pjesme i pripovijetke te poslovice i opise narodnih običaja, koje je objavljivao u književnim i zabavnim časopisima te u stručnim časopisima. ${ }^{29}$ Autor je prve hrvatske zbirke narodnih pripovjedaka za djecu - Narodne pripovedke, objavljene u Zagrebu 1879. Od početka svog profesionalnog rada u školskom sustavu sustavno je sakupljao različite plodove narodnog stvaralaštva - pjesme, pripovijetke, izreke, poslovice, najčešće putem usmene predaje, a sakupljao je i opise narodnih običaja. Takve je zapise objavio u nekoliko knjiga: Uprave za dobro i krěpostno vladanje, i někoje poslovice za mladež (Osijek, 1844); Slike iz domaćeg života slavonskog naroda i iz prirode s dodatkom Slavonske pučke sigre (Zemun, 1858); Sbirka narodnih poslovicah riečih i izrazah (Zagreb, 1866); Pučke pripoviedke i pjesme (Zagreb, 1867); Zabava i pouka za našu domaću mladež (Senj, 1877); Sbirka narodnih pripoviedaka. Sa tri dodatka: Narodne poslovice. Narodne zagonetke i Putopisnica (Senj, 1879); Slike iz života hrvatskoga naroda po Slavoniji i Sriemu (Zagreb, 1881). Zbog toga ga smatraju jednim od prvih hrvatskih etnologa. ${ }^{30}$ Sakupljanjem plodova jezičnog narodnog stvaralaštva Stojanović se uklopio u tada suvremene trendove. Naime, u 19. stoljeću u većini europskih zemalja bilo je vrlo popularno prikupljanje narodnog stvaralaštva. Primjerice, na njemačkom govornom području prikupljanjem, obradom i objavljivanjem različitih oblika usmenog narodnog stvaralaštva, a napose bajki, neizbrisiv trag ostavili su braća Jakob i Wilhelm Grimm.

Stojanović je napisao i nekoliko popularnih priručnika s korisnim savjetima o poljodjelstvu i voćarstvu, ${ }^{31}$ ponajprije namijenjenih seoskom stanovništvu. Stojanovićev angažman na očuvanju narodne baštine doveo je i do njegove suradnje s istaknutim hrvatskim publicistom i leksikografom 19. stoljeća Bogoslavom Šulekom, kojemu je pomagao u prikupljanju riječi i

${ }^{27}$ Riječ je o djelu Versuch einer Statistik der k. k. Militärgrenze des österreichischen Kaiserstaates, 3 sv. (Wien, 1817-1823).

${ }^{28}$ Mijat Stojanović, „Nješto iz povjestnice uredjivanja vojničke naše Krajine“, Arkiv, knj. 7 (Venecija, 1863), 72-91.

${ }^{29}$ Takve je radove ponajprije objavljivao u časopisima Danica ilirska, Neven, Naše gore list, Glasonoša, Slavonac, Gospodarski list i Arkiv za povjestnicu jugoslavensku.

${ }^{30}$ O Stojanoviću kao pučkom piscu i etnologu usp. Žigić, „Mijat Stojanović“; Tkalac, „Život i rad M. Stojanovića“.

${ }^{31}$ Voćarstvo. Uputa kako se dobiva svakojakih oplemenjenih voćakah mnogo i brzo i o malom trošku (Wien, 1869 i 1870); Uzorni ratar. Knjižica namienjena svim zemljodjelcem, ratarom ili težakom i njihovim prijateljem (Senj, 1876). 
izraza za njegovo kapitalno djelo Deutsch-kroatisches Wörterbuch - Němačkohrvatski rěčnik (2 sv., Zagreb, 1860.). Stojanović je objavio i priručnik s praktičnim uputama za pisanje različitih službenih dopisa (pisama, molbi, podnesaka) kakvi su se koristili u 19. stoljeću u poslovnom životu i javnoj upravi. ${ }^{32}$

\section{MIJAT STOJANOVIĆ O ŠKOLSTVU I PEDAGOŠKIM TEMAMA}

Najvažniji dio njegova publicističkog djelovanja vezan je za obrazovanje. O problemima hrvatskog školstva napisao je brojne tekstove, objavljene u političkim listovima Novine hèrvatsko-slavonsko-dalmatinske odnosno $\mathrm{Na}$ rodne novine i Slavenski jug te u časopisu Danica ilirska od sredine 1840-ih i tijekom 1850-ih godina, a kasnije u časopisu Napredak, najvažnijem pedagoškom časopisu u Hrvatskoj u 19. stoljeću. Svoje je tekstove potpisivao imenom i prezimenom, inicijalom imena i prezimenom, inicijalima ili šiframa $M$. St., St......ić ili Babinogredac (šiframa je najčešće potpisivao svoje članke do proglašenja slobode tiska u proljeće 1848. godine, kako je tada bilo uobičajeno i u drugim europskim zemljama), a moguće je da je neke tekstove objavio i anonimno.

Mijat Stojanović bio je prvi autor koji je u hrvatskim novinama 1845. godine počeo pisati o problemima hrvatskog pučkog školstva i mogućnostima njegova poboljšanja, ${ }^{33} \mathrm{i}$ to u vrijeme dok je u Hrvatskoj postojala stroga cenzura, zbog čega su politički listovi bili bezbojni i neaktualni. Zastupao je shvaćanje o socijalno-disciplinirajućoj ulozi škole u društvu, koje je bilo rašireno u 19. stoljeću. Glavna je svrha pučke škole, prema njegovu mišljenju, odgojiti dobre kršćane i domoljube te vjerne podanike, pri čemu iznimno važnu ulogu, ali i najveću odgovornost imaju učitelji. ${ }^{34}$ Kao glavne probleme koji otežavaju razvoj i napredak pučkoga školstva u Hrvatskoj naveo je slabo obrazovane i loše plaćene učitelje, koji zbog toga nisu motivirani za rad i stručno usavršavanje; loše odgojenu i odgojno zapuštenu djecu, koja

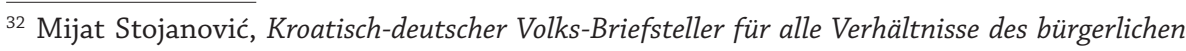
Lebens - Hrvatsko-njemački pučki listar za sva odnošenja gradjanskoga života (Agram, 1869).

${ }^{33}$ Bio je to članak M. S., „Něšto o pučkih naših učionicah“, NHSD, god. 10, br. 59 (24. 7. 1845).

${ }^{34}$ Slično je o odgojnoj i obrazovnoj ulozi učitelja te o problemima s kojima se u radu susreću pisao u svojoj autobiografiji: „Imao sam trudna posla i s' učitelji i s' učenici, dok je sve opet pošlo pravom stazom, pravim putem, po kome hodeć riešava učionica (tj. škola, op. aut.) svoju veliku zadaću i postiže svoju uzvišenu svrhu, naime naobraziti iz djece ljude, koji se svojim razumom valjano služe, koji ćudoredno dobro misle i govore i tvore, i u zvanju, za koje su u gradjanskom družtvu odredjeni valjani jesu. Zapriekah mi puno stajaše na putu i od strane roditeljah, koji školu svojim domaćim odgojenjem djece slabo i nikako nepodupiraju ponajviše iz neznanstva i nehajstva, i od strane učiteljah, koji neposvećuju i neulažu sve svoje sile tjelesne i duševne u riešenje svoje uzvišene zadaće, nego učiteljuju kao najmenici, i napokon od strane u takvih okolnostih zanemarene učeće si mladeži." Stojanović, Sgode i nesgode, 93. 
neredovito pohađaju nastavu (jer obitelj treba njihovu pomoć u svakodnevnim poslovima i jer roditelji ne uviđaju korist obrazovanja); slabu suradnju učitelja i roditelja te učitelja i župnika/vjeroučitelja te loše opremljene škole i nekvalitetne udžbenike. ${ }^{35}$ Predložio je i sredstva za poboljšanje kvalitete pučkog školstva u Hrvatskoj: bolje obrazovanje i poboljšanje materijalnog i društvenog položaja učitelja, koji bi se bez brige za osiguranje svakodnevne egzistencije za svoju obitelj mogli posvetiti stručnom usavršavanju (najbolji primjer za to dao je sam svojim ustrajnim samoobrazovanjem na različitim područjima); bolja suradnja učitelja i roditelja, koji bi trebali znati svoje obveze prema školi i djecu redovito slati u školu; kvalitetni i primjereni udžbenici; proširenje kurikula uključivanjem nacionalne (tj. hrvatske) povijesti i geografije te uvođenje ilirske gramatike i pravopisa u škole. ${ }^{36}$

Mijat Stojanović pokazao je kako bi, prema njegovu mišljenju, trebala izgledati dobro uređena osnovna škola. Trebala bi imati dobro osvijetljene, prozračene i prikladno namještene učionice, njegovan školski vrt s povrtnjakom i voćnjakom te igralište za tjelovježbu. Učenici bi trebali biti uredni i pristojni i redovito dolaziti na nastavu, a nastavnici bi dobivali dobru plaću i uživali materijalnu i svaku drugu potporu lokalne zajednice i župnika te ostvarili kvalitetnu suradnju s roditeljima. Novac dobiven prodajom voća i povrća iz školskog vrta koristio bi se za kupnju knjiga siromašnim učenicima i knjiga za školsku knjižnicu. U takvim školama učenici bi bili motivirani za učenje i lakše bi stjecali kvalitetno znanje. ${ }^{37}$ Zakonski temelj za takvu školu postavljen je dvadeset pet godina kasnije u prvom zakonu o školstvu koji je donio Hrvatski sabor, tzv. Mažuranićevu zakonu iz 1874. godine. ${ }^{38}$

${ }^{35}$ Mijo Stojanović, Babinogredac, „Něšto o pučkih naših učionicah“, NHSD, god. 10, br. 64 (9. 8. 1845), br. 65 (13. 8. 1845), br. 69 (27. 8. 1845); M. St., „Iz Slavonie 16. prosinca“, $N N$, god. 15, br. 222 (21. 12. 1849). Na osnovi vlastitog iskustva opisao je primjer odlične suradnje učitelja i župnika u članku M. St., „Iz Slavonie 22. studenog“, NN, god. 15, br. 204 (29. 11. 1849).

${ }^{36}$ M. S., „Něšto o pučkih naših učionicah“, NHSD, god. 10, br. 59 (24. 7. 1845); Mijo Stojanović, Babinogredac, „Něšto o pučkih naših učionicah“, NHSD, god. 10, br. 70 (30. 8. 1845); M. St., „Iz Slavonie 16. prosinca“, NN, god. 15, br. 222 (21. 12. 1849).

${ }^{37}$ Mijat Stojanović, učitelj, „Školski izpit u jednom Slavonskom selu“, SJ, god. 2, br. 69 (12. 6. 1849). Zanimljivo je da je Stojanović svoj ideal škole opisao u priči o školskom ispitu u jednom selu za koji se na kraju teksta pokazalo da je bio samo san.

38 O tom zakonu i njegovoj ulozi u modernizaciji hrvatskog školstva usp. Dinko Župan, Pučko školstvo u vrijeme banovanja Ivana Mažuranića, magistarski rad (Filozofski fakultet Sveučilišta u Zagrebu, 2002), 44-59; D. Župan, „Mažuranićeva reforma pučkoga školstva“, u: Intelektualac, kultura, reforma: Ivan Mažuranić i njegovo vrijeme. Zbornik radova, ur. Dalibor Čepulo, Tea Rogić Musa i Drago Roksandić (Zagreb, MMXIV-MMXIX), 265-282; Mirko Raguž, „Zakon od 14. listopada 1874. ob ustroju pučkih škola i preparandija za pučko učiteljstvo u Kraljevinah Hrvatskoj i Slavoniji“, Senjski zbornik 37 (2010), 87-98; Sonja Gaćina Škalamera, „Zakon o pučkim školama i preparandijama u Kraljevinama Hrvatskoj i Slavoniji iz 1874. godine. Sto četrdeseta obljetnica hrvatskoga zakona o obveznom obrazovanju“, 
Stojanović je pisao i o odgojnoj ulozi učitelja i škole. Polazio je od premise da je čovjek po prirodi, ako izostane pozitivan utjecaj odgoja, lijen, lakomislen, bojažljiv, podao, drzak, osvetoljubiv i podložan strastima. Takav čovjek, prema Stojanovićevu mišljenju, može biti štetan za društvo, ali i za samoga sebe. Da bi se nekog čovjeka učinilo korisnim i poštenim državljaninom i članom (lokalne) zajednice njegovo obrazovanje i odgoj moraju se temeljiti na poštivanju zakona i običaja i na unutarnjoj preobrazbi. Razvoj humanosti kao najviši cilj čovječanstva (ideja istaknutog njemačkog filozofa i teologa Johanna Gottfrieda Herdera) ${ }^{39}$ i ostvarenje onoga po čemu se čovjek razlikuje od životinja, prema Stojanovićevu su mišljenju plod uspješnog obrazovanja i odgoja u školi i obitelji. Zbog lošeg kućnog odgoja djece u Hrvatskoj pučke škole uz redovitu obrazovnu i odgojnu ulogu imaju i dodatnu odgojnu ulogu - nadomjestiti manjkav kućni odgoj. Mijat Stojanović je, poput većine drugih obrazovanih i javno aktivnih ljudi u Hrvatskoj u 19. stoljeću, prosvjećivanje naroda, nacionalnu samostalnost i odgoj mladeži u nacionalnom duhu držao važnim preduvjetima za razvoj svih aspekata političkog, društvenog, kulturnog i gospodarskog života Hrvatske, a njih nije bilo moguće ostvariti bez dobro organizirane pučke škole. Jednako tako, držao je da jedino kvalitetna pučka škola može omogućiti građanima da upoznaju svoja građanska prava i obveze i da se ostvare načela slobode, jednakosti i bratstva, koja su nakon izbijanja revolucije 1848. postala lajtmotiv ukupnog političkog djelovanja (umjereno) liberalno orijentiranih snaga u Hrvatskoj (slično kao i u drugim europskim zemljama), kojima je pripadao i Stojanović. Držao je da je glavna svrha ljudskog postojanja razvoj vlastitih umnih, duhovnih i tjelesnih sposobnosti, što nije moguće ostvariti bez kvalitetne pučke škole. ${ }^{40}$ Bio

Anali za povijest odgoja 13 (2014), 99-133 i Ivana Horbec, Maja Matasović i Vlasta Švoger, „Zakonodavni okvir stvaranja modernoga školstva u Hrvatskoj (18. i 19. stoljeće)“, u: Od protomodernizacije do modernizacije školstva u Hrvatskoj. Knjiga I: Zakonodavni okvir, prir. Ivana Horbec, Maja Matasović i Vlasta Švoger (Zagreb 2017), 40-42, 353-386. histedu. isp.hr/histedu/wp-content/uploads/2015/07/Institut-MODERNIZACIJA-SKOLSTVA.pdf, pristupljeno 16. 11. 2019.

${ }^{39}$ Zanimljivo je da se Stojanović ovdje izravno ne referira na J. G. Herdera čije je ideje o razvoju humanosti preuzeo. Sigurno je, međutim, da je Herderove ideje dobro poznavao jer ih je, između ostalih, navodio u nizu članaka „Pisma starog učitelja svomu mladomu drugu“ o kojima će biti riječi kasnije. O recepciji Herderovih ideja u Hrvatskoj usp. Nikola Ivanišin, „J. G. Herder i ilirizam", Radovi Filozofskog fakulteta u Zadru (Zadar), god. 2, br. 2, 1963, 196225; Wolfgang Kessler, „Die Südslawen und Herder. Einige Anmerkungen“, u: Festschrift für Wolfgang Gesemann, Band 3, Beiträge zur slawischen Sprachwissenschaft und Kulturgeschichte (München, 1986), 157-175; Vlasta Švoger, „Recepcija Herdera u hrvatskome narodnom preporodu na temelju Danice ilirske“, Časopis za suvremenu povijest (Zagreb), god. 30, br. 3, 1998, 455-478.

40 Babinogredac, „Niešto o izobraženosti“, Danica ilirska (Zagreb), god. 15, br. 31 (30. 6. 1849); Mijat Stojanović, učitelj, „O učionici“, SJ, god. 1, br. 31 (15. 10. 1848); Mijo Stojanović, učitelj, „Srědstvo, kojim bi se mogla pobudit kod prostog, neukog puka ljubav prama knjigam 
je uvjeren da u tom procesu učitelji imaju iznimno važnu ulogu. Zbog toga je svoje kolege upozoravao na to koliko je odgovorna i časna njihova uloga u društvu. Da bi je mogli uspješno ostvariti, nužno je da se neprestano stručno usavršavaju čitajući pedagošku literaturu i primjenjujući u nastavi korisna iskustva svojih kolega. Također im je savjetovao da se učenicima obraćaju s ljubavlju, poštovanjem i brigom te bez pretjerane strogosti. ${ }^{41} \mathrm{O}$ tome koliko je M. Stojanović držao važnim odnos učitelja prema učenicima i prijenos ideja i iskustava sa starijih na mlađe kolege svjedoči niz od dvanaest članaka naslovljenih „Pisma starog učitelja svomu mladomu drugu“ u kojima je vrlo detaljno pisao o tome. Zanimljivo je da je za obradu te teme odabrao vrlo osoban oblik izražavanja; naime, članci su formulirani u obliku pisama kao odgovor iskusnog učitelja na pitanja mladog kolege. U tim je člancima analizirao ulogu svih čimbenika koji sudjeluju u odgoju djece: roditelja, učitelja, odnosno škole, crkve i prirode. Budući da učitelji svoju ulogu u odgoju djece započinju kasnije od ostalih navedenih čimbenika, moraju djelovati usklađeno s njima, ali i korektivno. Ulogu učitelja u odgoju školske djece analizirao je i prikazao vrlo detaljno, pri čemu je dao i brojne korisne praktične savjete. Njegovi savjeti nisu se temeljili samo na vlastitom iskustvu, nego je citirao ili parafrazirao misli i ideje istaknutih europskih filozofa od antičkih vremena do njemu suvremenog vremena (Aristotela, Platona, Sofokla, Katona Starijeg, Gottfrieda Wilhelma Leibnitza, Johanna Gottfrieda Herdera, austrijskog liječnika, pjesnika i filozofa Ernsta von Feuchterslebena, koji se 1848. godine angažirao u reformi obrazovnog sustava u Habsburškoj Monarhiji, te teologa i estetičara J. G. M. Durscha). ${ }^{42}$

Želeći olakšati kolegama učiteljima rad s djecom s poremećajima u ponašanju, u dva je članka analizirao najčešće poremećaje u ponašanju kod djece (zaboravljivost, nepažljivost, bijes, svojeglavost i obijest) i odgojne postupke koji mogu pomoći u smanjivanju njihova negativnog učinka na nastavu te olakšati takvim učenicima usvajanje znanja. ${ }^{43}$

i narodnoj književnosti, i tako uskorit prosvěta cělog naroda", NDHS, god. 13, br. 29 (10. 4. 1847); M. Stojanović, učitelj, „Nešto o izobraženosti“, SJ, god. 2, br. 76 (28. 6. 1849); M. St., „Iz Slavonske krajine 14. rujna“, NN, god. 15, br. 146 (21. 9. 1849).

${ }^{41}$ M. St. „Niekoliko riečih učiteljima naših narodnih učionah pri koncu ljeta 1849 od njihova sudruga“, NN, god. 15, br. 227 (29. 12. 1849).

42 „Pisma starog učitelja svomu mladomu drugu. Od M. St., učitelja“, NN, god. 24, br. 95 (27. 4. 1858) do br. 110 (15. 5. 1858). Zanimljivo je da je Stojanović u to vrijeme imao samo 40 godina, ali i 25 godina iskustva rada u školi. U br. 105 (8. 5. 1858) donosi citat iz Durscheve Pedagogike. Riječ je o Johannu Georgu Martinu Durschu (1800.-1881.), njemačkom katoličkom teologu i estetičaru i njegovu djelu Pädagogik oder Wissenschaft der christlichen Erziehung auf dem Standpunkt des katholischen Glaubens, objavljenom u Tübingenu 1851. To upućuje na zaključak da je Stojanović pratio recentnu pedagošku literaturu.

${ }^{43}$ M. Stojanović, „Razgovor o ćudorednim falingama djece“, SJ, god. 2, br. 76 (28. 6. 1849) i br. 77 (30. 6. 1849). 
U časopisu Napredak Stojanović je objavljivao dulje članke o pedagoškim temama koji su izlazili u nekoliko nastavaka. ${ }^{44}$

U nizu članaka naslovljenih Crtice iz povjestnice obučavanja i odgojivanja ${ }^{45}$ Stojanović je analizirao razvoj obrazovanja i školstva od staroga vijeka do njemu suvremenog doba. Prikazao je glavnu svrhu i obilježja obrazovanja u Kini, Indiji, kod Perzijanaca, Egipćana, Židova, Grka i Rimljana, istaknuo je glavne ideje o obrazovanju koje su zastupali najvažniji grčki filozofi koji su također bili angažirani i kao učitelji. ${ }^{46} \mathrm{Za}$ razdoblje nakon sloma Rimskog Carstva koncentrirao se na prikaz obrazovanja u Europi i doprinos kršćanskih redova razvoju obrazovanja. Kritički je ocijenio razvoj privatnog i javnog obrazovanja u europskim zemljama od srednjega vijeka nadalje i ulogu pojedinih istaknutih školskih reformatora i pedagoga. Zanimljivo je da je bio vrlo kritičan prema Jeanu Jacquesu Rousseauu, kojega je nazvao „razvikanim“ i ocijenio da nije bio praktični odgojitelj, jer je vlastitu djecu dao u sirotište na odgoj i obrazovanje. Rousseauova shvaćanja o odgoju kritizirao je ponajviše zbog toga jer je nastojao smanjiti ulogu crkve u obrazovanju. Iz istog je razloga Stojanović kritizirao i svoga suvremenika Adolpha Diesterwega, za kojega je napisao da je bio „prvi borac za to, da se emancipira škola od crkve, koji, čini mi se u tom obziru sa ljuskom i jezgru baca“. ${ }^{47}$

Stojanović je bio jedan od prvih hrvatskih pedagoga koji se zalagao za to da se ženskoj djeci iz različitih društvenih slojeva omogući i stjecanje različitih praktičnih znanja i vještina koje bi im omogućile da vlastitim radom izvan kuće ili u okviru vlastitog kućanstva pridonesu kućnom budžetu. Pritom nije dovodio u pitanje dominantnu poziciju muškarca u obitelji i društvu, kao onoga koji treba osigurati materijalnu podlogu za život obitelji i koji raspolaže imovinom koju je žena donijela u brak. Kritizirao je domete njemu suvremenog školovanja ženske djece, koje je osobito kod djevojaka srednjih

${ }^{44}$ Zbog ograničenja opsega ovoga rada, kao i zbog velikog broja članaka koje je Stojanović objavio u časopisu Napredak, ovdje će se analizirati samo najzanimljiviji. Zbog istog razloga neće se analizirati ni radovi o temama vezanim za školstvo objavljeni u drugim časopisima, u kojima je zastupao slična shvaćanja kao ona već analizirana i prikazana u ovome radu. Dosad najpotpuniju bibliografiju radova Mijata Stojanovića donosi Dinko Župan, „Bibliografija radova Mijata Stojanovića“, u: Sgode i nesgode, 285-299.

${ }^{45}$ Mijat Stojanović, „Crtice iz povjestnice obučavanja i odgojivanja“, Napredak. Časopis za učitelje, odgojitelje i sve prijatelje mladeži (dalje: Napredak) (Zagreb), god. 6, br. 3 (1. 2. 1865) do br. 9 (1. 5. 1865). Članci su objavljeni i kao posebna brošura: M. Stojanović, Crtice iz povjestnice pedagogike (Zagreb, 1865).

${ }^{46}$ O pedagoškim shvaćanjima i djelovanju Platona i Aristotela kasnije je napisao posebne članke: Mijat Stojanović, „Dvie tri Platonove o javnom odgojenju“, Napredak, god. 9, br. 8 (15. 5. 1868) i br. 9 (1. 6. 1868); M. Stojanović, „Dvie tri Atistotelesove o javnom odgojenju“, Napredak, god. 9, br. 12, (15. 7. 1868).

${ }^{47}$ Stojanović, „Crtice iz povjestnice obučavanja i odgojivanja“, Napredak, god. 6, br. 7 (1. 4. 1865) i br. 9 (1. 5. 1865), citat br. 9, str. 136. 
i viših građanskih (i plemićkih) slojeva bilo usmjereno prema stjecanju znanja iz opće kulture (učenje francuskog i njemačkog jezika, osnova književnosti, sviranja i pjevanja, salonskih manira, ženskog ručnog rada i osnova vođenja kućanstva), i to s ciljem stjecanja kvalifikacija za bračno tržište. Po uzoru na žene iz nižih društvenih slojeva koje su obavljale mnogo različitih poslova u okviru kućanstva i izvan njega (kućanice, kuharice, pekarice, vrtlarice, prelje, krojačice itd.), Stojanović drži da bi i žene iz srednjih slojeva školovanjem trebale steći korisna znanja kojima bi si osigurale budućnost. Uvelike je iskoračio iz tada dominantne predodžbe o muškim i ženskim poslovima te o muškim i ženskim mentalnim sposobnostima, napisavši sljedeće: „Odhranjenjem domaćim i školskim treba da učinimo iz ženske djece pametne, razumne i vješte žene (...) Zašto nebi ženske mogle biti činovnici državni i osim učiteljskog zvanja, kad mogu biti učiteljice? Mogu biti krojači, cipelari, tkalci, bojadisari, pletari, kuvari, pekari, sitari; (...) mogu biti zanatnici ženskih i mužkih nakitah i nadziratelji mnogih obćepoleznih zavodah: bolnicah, sirotištah itd. Ženske su glave isto onako ukrašene s darovi uma i srca, ko i mužke osobe. "“8 Slična situacija s obrazovanjem djevojaka srednjih i viših društvenih slojeva u 19. stoljeću bila je i u drugim europskim zemljama, a najpoznatiji muškarac koji je oštro osuđivao diskriminaciju žena i borio se za njihovu ravnopravnost u društvu, uključujući i dobivanje prava glasa, bio je britanski filozof i politički ekonomist John Stuart Mill. ${ }^{49}$

Obrazovnu i odgojnu ulogu pučke škole u društvu, iznimno odgovornu ulogu učitelja pučke škole u odgajanju i obrazovanju novih naraštaja, karakterne osobine koje učitelj mora imati da bi mogao kvalitetno raditi svoj posao i potrebu kontinuiranog i ustrajnog rada učitelja na proširivanju vlastitih znanja i spoznaja Stojanović je vrlo detaljno analizirao u nizu članaka naslovljenih „Misli o pučkoj prosvjeti i o pučkih učionah“. Prema njegovu mišljenju: „Biti učiteljem, to je najveća čast, koja čovjeku na ovom svietu u dio pasti može, jer ni Spasitelj svieta nije bio drugo što na zemlji, nego učitelj." Razmatrao je i brojne probleme s kojima se u svakodnevnom životu susreću učitelji, ali i probleme hrvatskog pučkog školstva na organizacijskoj i provedbenoj razini. Pretresao je

${ }^{48}$ Mijat Stojanović, „Pedagogički odlomci“, Napredak, god. 1, br. 8 (15. 1. 1860) do br. 15 (1. 6. 1860), citat br. 11, str. 165.

49 O obrazovanju žena u Hrvatskoj u kontekstu obrazovanja žena u europskim zemljama piše Dinko Župan, Mentalni korzet. Spolna politika obrazovanja žena u Banskoj Hrvatskoj (18681918) (Osijek - Slavonski Brod, 2013), 25-45. O obrazovanju žena u Hrvatskoj u 19. stoljeću usp. i: Ida Ograjšek Gorenjak, „On uči, ona pogađa, on se sjeća, ona prorokuje - pitanje obrazovanja žena u sjevernoj Hrvatskoj krajem 19. stoljeća“, u: Žene u Hrvatskoj - ženska i kulturna povijest, ur. Andrea Feldman (Zagreb, 2004), 157-179; I. Ograjšek Gorenjak, „Zastupljenost ženskog pitanja u hrvatskim glasilima na kraju 19. stoljeća“, Radovi Zavoda za hrvatsku povijest 34-36 (2004), 89-100; I. Ograjšek Gorenjak, Otvaranje Privremenog ženskog liceja i položaj građanskih žena u Hrvatskoj na kraju 19. stoljeća, magistarski rad (Filozofski fakultet Sveučilišta u Zagrebu, 2005). 
i problem nedovoljno kvalificiranih učitelja i preduvjete za uspostavu kvalitetnih narodnih škola. Kao preduvjete za poboljšanje kvalitete škola ponovno je naglasio potrebu osnivanja kvalitetnih učiteljskih škola i povećanja plaća svih učitelja, držao je da bi upravljanje školama i nadzor nad njima trebalo dati u ruke ljudima koji su iskreno zainteresirani za napredak narodne prosvjete, trebalo bi izraditi kvalitetne udžbenike u narodnom duhu i učiteljima osigurati pristojne mirovine. Držao je također da bi sva za školu sposobna djeca morala redovito ići u školu od 6. do 12. godine, a nakon toga u nedjeljnu školu ili opetovnicu do navršene 15. ili 16. godine. Očekivao je i veći angažman roditelja školske djece: „Roditelji moraju se svojski zauzeti za narodne škole i svojim dobrim domaćim odhranjenjem školskom ići na ruku. ${ }^{\text {50 }}$ Dakle, prema njegovu mišljenju, samo suradnjom i sinergijom svih čimbenika koji utječu na funkcioniranje pučkih škola može se osigurati kvalitetno osnovno obrazovanje koje će postati preduvjet za napredak društva i omogućiti da učenici u budućnosti mogu postati dobri domoljubi i građani koji poznaju svoja prava i dužnosti.

Odgojnu ulogu škole, odnosno učitelja detaljno je analizirao u nizu članaka naslovljenom „O školskom zaptu = redu, u obće gojitbi“, pod čime podrazumijeva „ono djelovanje učionice kojim se privode djeca uz nauku i školsko uredjenje k nabožno-ćudorednomu ponašanju u učionici“. Odgojnim djelovanjem, prema Stojanovićevu mišljenju, pučka škola kod učenika treba razviti sljedeće osobine: „Poslušnost, poniznost i čednost, molitvu i ljubav za službu božju, pozornost, red i poredak, čistoću, postidnost, istinitost, počitanje tudjih pravah, udioničtvo pri svakom udesu svojih bližnjih, uljudnost, pristojnost, uslužnost, dobrotu, blagost, blagonaklonost, blagotvornost." Da bi učitelj na odgovarajući način mogao odgojno djelovati na učenike i nastojati kod njih razviti moralno poželjne osobine mora poznavati ljude, a osobito djecu, njihovu ćud, emocije i razlike u ponašanju. Budući da se djeca međusobno znatno razlikuju, učitelj svakom djetetu treba pristupati individualizirano. Stojanović daje konkretne preporuke kako pristupiti pojedinom djetetu s obzirom na njegove glavne karakterne osobine, sposobnosti, ali i na obiteljske okolnosti, te koje odgojne metode uporabiti da bi se kod djeteta potaknuo razvoj poželjnih osobina. Učitelj djeci treba iskazivati očinsku brigu, ljubav i poštovanje i svojim ponašanjem pružati im pozitivan primjer u koji se mogu ugledati. Učitelj djecu u školi treba navikavati na održavanje čistoće, urednost i red, na poslušnost, pažljivost, ljubaznost i uslužnost, poticati ih da budu vesela, iskrena, čedna i pristojna. Da bi učitelj mogao biti dobar odgajatelj treba uživati poštovanje, povjerenje i ljubav svojih učenika. Kako bi stekao njihovo poštovanje, mora biti nepristran, pravedan, razborit, ljubazan, treba ostvariti ravnotežu između blagosti i strogosti i treba uče-

$\overline{50}$ Mijat Stojanović, „Misli o pučkoj prosvjeti i o pučkih učionah“, Napredak, god. 3, br. 11 (1. 3. 1862) do br. 21 (1. 8. 1862). Citati br. 11, str. 168 i br. 16, str. 246. 
nike naviknuti na poštivanje školskih uredaba i njihovih obveza, jer će tako naučiti da moraju poštovati sve zakone. Stojanović savjetuje učiteljima kako da primjenjuju nagrade i kazne, a kao osnovno načelo preporučuje da uvijek pokušaju blagim i ljubaznim načinom ostvariti red i potaknuti učenike na poželjno ponašanje te da pribjegnu strogosti i kazni tek ako ljubaznost ne poluči željeni uspjeh. Preporučuje da nagrade i kazne ne primjenjuju često jer će izgubiti smisao i upućuje učitelje da ih vrlo pažljivo koriste: „Samo prava zasluga, pomnja, prilježnost i ono, što se steče vlastitom snagom, svojim trudom i naporom, zaslužuje, da se nagradi, ali prirodjene osobite sposobnosti i darovi uma nezaslužuju to; kaogod što se nipošto, nikako i nikada nemogu i nesmiju kazniti prirodjena nesposobnost i nezaslužena slabost, nego samo djelovanja proiztekavša iz nemarnosti, iz nehajstva, iz lakomišljenosti i lienosti, te učinci pokvarene, izopačene, zle volje." Učiteljima savjetuje da tjelesne kazne primjenjuju samo u krajnjoj nuždi, nakon što su iscrpili sva blaža sredstva, da pribjegnu tjelesnoj kazni samo kad su sigurni tko je krivac, da nikada ne šibaju učenike bez dogovora s ravnateljem i da tu kaznu provode, ako je moguće, u nazočnosti roditelja, da se izbjegne mogućnost ljutnje i eventualne tužbe. Primjenom odgovarajućih odgojnih metoda u školi učitelj će potaknuti djecu da se pristojno ponašaju i izvan škole, a najbolji rezultati u odgoju djece postižu se ako roditelji, učitelj i župnik/vjeroučitelj surađuju. ${ }^{51}$

Stojanović je na temelju vlastitog iskustva i preporuka istaknutih pedagoga davao konkretne didaktičke savjete kolegama učiteljima, napose vezano za podučavanje materinjeg jezika i za istodobno podučavanje učenika različitih razreda u jednoj učionici. ${ }^{52} \mathrm{U}$ nekoliko je članaka razmatrao na koji bi način pučka škola mogla pridonijeti razvoju gospodarstva u Hrvatskoj. ${ }^{53}$ Detaljno je analizirao odnos učitelja prema različitim čimbenicima s kojima učitelj surađuje u svom radu te onima koji sudjeluju u organizaciji pučke škole (učenicima, roditeljima, općini u kojoj djeluje škola, župniku, vjeroučitelju, učiteljevim pomoćnicima i kolegama, nadređenima i državi) i zaključio da je temelj uspješne suradnje sloga i međusobno poštovanje. ${ }^{54}$

${ }^{51}$ Mijat Stojanović, „O školskom zaptu = redu, u obće gojitbi“, Napredak, god. 8, br. 1 (1. 1. 1867) do br. 7 (1. 4. 1867), citati br. 1, str. 9 i br. 5, str. 70.

${ }^{52}$ Mijat Stojanović, „Didaktički ulomci posebnim obzirom na materinski jezik“, Napredak, god. 5, od br. 8 (15. 4. 1864) do br. 24 (15. 12. 1864); Isti, „Ako koja učionica imade samo jednu sobu, u kojoj se obučavaju skupa veća i manja djeca: kako se imade obučavati postepeno, da bude nauke[a!] za sve koristna?", Napredak, god. 2, br. 16 (15. 5. 1861).

${ }^{53}$ Mijat Stojanović, „Pučka učionica i gospodarstvo“, Napredak, god. 2, br. 12 (15. 3. 1861); Isti, „Bili mogla pučka učionica pripomoći unapredjenje materialnog blagostanja našega naroda?“, Napredak, god. 8, br. 8 (15. 4. 1867); Isti, „O pripomaganju unapredjenja materialnog blagostanja naroda od strane pučke učionice", Napredak, god. 8, br. 10 (15. 5. 1867).

${ }^{54}$ Mijat Stojanović, „Misli s polja promatranja pučke učionice“, Napredak, god. 2, br. 9 (1. 2. 1861) i br. 10 (15. 2. 1861). 
Mijat Stojanović autor je nekoliko školskih udžbenika. Na zahtjev skupštine učitelja Vojne krajine, održane u Petrinji 1850., napisao je Slovnicu za porabu početnih pučkih učiona u vojničkoj krajini, ali nije tiskana zbog (osobno motivirane) negativne recenzije Stjepana Antolića. Bukvar iliti početnu čitanku tiskao je u Srijemskim Karlovcima 1851. Petnaestak godina kasnije (1867.) napisao je gramatičke udžbenike za njemački jezik za II., III. i IV. razred glavnih i trivijalnih škola u Vojnoj krajini i poslao ih u Beč na stručnu ocjenu. ${ }^{55}$ Nije bilo moguće utvrditi razlog zbog kojega nisu tiskani.

Napisao je i nekoliko djela pedagoške tematike: Učba za učitelje pučke učionice (1862.), ali su stručni recenzenti držali da djelo nije dovoljno sustavno napisano i nisu preporučili objavu; ${ }^{56}$ Crtice iz povjestnice pedagogike (Zagreb, 1865, objavljene i u časopisu Napredak), Zablude uzgoja. Preradio prema narodnom domaćem uzgoju Mijat Stojanović (riječ je o prijevodu i preradi, odnosno prilagodbi prilikama u Hrvatskoj knjige Krebsbüchlein njemačkog pedagoga Christiana Gotthilfa Salzmanna, Zagreb, 1873.). Posmrtno je objavljeno Stojanovićevo djelo Milan Dragojević. Pedagogijska pripoviest (prijevod djela Konrad i Kiefer njemačkog pedagoga Ch. G. Salzmanna, Zagreb, 1882.). Stojanović je s njemačkog preveo knjigu svoga suvremenika, istaknutog austrijskog pedagoga Friedricha Dittesa Grundris der Erziehungs und Unterrichtslehre, preradio je i prilagodio prilikama u Hrvatskoj pod nazivom Jezgra nauke ob odgajivanju i nastavi. Preveo je i Dittesovu knjigu Lehrbuch der praktischen Logik (prevedena pod naslovom Praktično umoslovje). ${ }^{57}$ Oba je rukopisa poslao u Zagreb na stručnu ocjenu. Prvu od spomenutih knjiga Zemaljsko zapovjedništvo u Zagrebu namjeravalo je tiskati i Stojanoviću je obećana naknada za to; međutim, katoličko svećenstvo se usprotivilo tiskanju knjige jer je Dittes bio protestant i knjiga nije tiskana (jednako kao ni udžbenik iz logike).$^{58}$ U Stojanovićevoj ostavštini u Hrvatskom školskom muzeju sa-

${ }^{55}$ U Hrvatskom školskom muzeju, Ostavština Mijata Stojanovića, A771 (dalje: HŠM, A771 Stojanović, Mijat) čuvaju se izvornici udžbenika za II. i III. razred: Slovnica njem. j. za drugi razred glavnih i trivialnih učionica u Hrv.-slav. krajini (1867.) i Slovnica njem. j. za treći razred glavnih i trivialnih učionica u Hrv.-slav. krajini (1867.).

${ }^{56}$ Stojanović, Sgode i nesgode, 97. Izvornik je pohranjen u HŠM, A771 Stojanović, Mijat.

${ }^{57}$ Friedrich Dittes (1829.-1896.) bio je austrijski liberalni pedagog, od 1868-1881. ravnatelj više škole za obrazovanje učitelja Pädagogium u Beču. Zalagao se za razvoj školstva slobodnog od vanjskih utjecaja. Zbog toga je došao u sukob s crkvenim krugovima i morao je odstupiti. Svoja pedagoška shvaćanja formulirao je pod utjecajem Friedricha Eduarda Benekea, Jana Amosa Komenskog, Johanna Heinricha Pestalozzija i Adolpha Diesterwega. Richard Meister, „Dittes, Friedrich“, Neue Deutsche Biographie 4 (1959), 2-4 [Online-Version]; URL: https://www.deutsche-biographie.de/pnd118679872.html\#ndbcontent, pristup 19. 11. 2019.

58 Tkalac, „Rad Mijata Stojanovića kao školnika“, 85-86. Oba Stojanovićeva rukopisa datirana su 1872. godine i čuvaju se u HŠM, A771 Stojanović, Mijat. Stojanovićev komentar o tom događaju: „Dittesovo spomenuto djelo pospješilo bi višju naobraženost naših pučkih učite- 
čuvan je još jedan rukopis o odgojnoj tematici. Riječ je o djelu Diete. Savjeti za roditelje i odgojitelje, prijevodu djela francuskog katoličkog biskupa Felixa Dupanloupa. ${ }^{59}$ Stojanović je očito redovito pratio inozemnu recentnu pedagošku literaturu, jer su prva izdanja spomenutih knjiga objavljena između 1868. i 1871. godine.

Na kraju navodim Stojanovićevu ocjenu stanja u školstvu u Hrvatskoj u 19. stoljeću koja se može shvatiti i kao sukus njegova pedagoškog djelovanja: „Sve se poziva na izdane propise, i liepo se piše i liepo čita crno na bielu, samo u životu nevidim pravoga napredka i uspjeha, i neće toga ni biti, dokgod se neslože svi faktori, što su pozvani sudjelovati promicati sveobću pučku prosvjetu: državne vlasti, škola, crkva, dom ili kuća, obćina; dok nelipsa krivi duh stanovitih kasta crnih i šarenih; dok pedagogija nezauzme mjesto svoje pravo medju srodnicami si bogoslovijom, filozofijom, pravoslovjem, medicinom i drugimi znanosti; ona je upravo temeljna znanost i osnov za sve druge znanosti i umjetnosti, kakogod što se početnom, osnovnom pučkom učionicom polaže temelj za srednje škole, realke, gimnazije, trgovačke, obrtničke, ratarske i druge takove škole i za ista sveučilišta. "60

\section{ZAKLJUČAK}

Mijat Stojanović svojim je marljivim i ustrajnim samoobrazovanjem i kontinuiranim usavršavanjem na različitim područjima (čitanjem stručne literature vezane za razne školske predmete, stručne pedagoške literature, književnih djela, literature iz politike i gospodarstva, političkih listova, stručnih časopisa i drugih tekstova) i na raznim jezicima (njemački, hrvatski, slovenski i češki) stekao vrlo široko znanje, koje je prenosio u učionici,

lja, nu tomu se protive naši popovi, jerbo je pisac Luteran, pak bi, misle njegova uzgojna i obučna načela mogla škoditi katolicizmu. Vara se ljuto, tko tako sudi o tom djelu. Dittes nije pisao svoju jezgru nauke ob uzgojivanju i nastavi kao Luteran nego kao praktični pedagog i vjerozakonskoj nauki i obuki u pučkoj školi opredjelio je pravo mjesto, koje joj po zrelih načelih napredne i umne pedagogije ide. Njemu je vjera sveta al' i razum u čovjeku duševno ako i velik božji dar, proti komu tko grieši, nemože postati savršenim, pravim čovjekom." Stojanović, Sgode i nesgode, 194.

${ }^{59}$ HŠM, A771 Stojanović, Mijat. Félix Dupanloup (1802.-1878.) bio je jedan od vođa liberalnog katolicizma u Francuskoj, član Francuske akademije znanosti, jedan od protivnika dogme o papinoj nezabludivosti na I. vatikanskom koncilu. Stojanović je preveo njegovo djelo L'Enfant (Paris, 1869). https://en.wikipedia.org/wiki/F \%C3\%A9lix_Dupanloup, pristupljeno 19. 11. 2019. Djelo je preveo 1873. ili 1874. godine, jer je na rukopisu uz svoje ime naveo da je „nadzornik narodnih škola u ogulinskom okružju“. Vjerojatno je prijevod napravio na temelju njemačkog izdanja knjige naslovljenog Das Kind. Ratschläge für Eltern und Erzieher, objavljenog u Mainzu, 1869. godine, jer u svojoj autobiografiji ne spominje da je učio francuski jezik.

${ }^{60}$ Stojanović, Sgode i nesgode, 194. 
u udžbenicima i drugim knjigama koje je napisao te u brojnim objavljenim člancima u političkim listovima i stručnim časopisima. Preveo je i nekoliko pedagoških djela njemu suvremenih autoriteta na području pedagogije, koja nažalost nisu objavljena. Idejama i znanjima iz područja pedagogije, kao i onima o političkim institucijama, napose o ustavnosti i parlamentarizmu, koje je upoznavao čitajući stranu literaturu i časopise, pristupao je kritički i ocjenjivao ih je iz perspektive mogućnosti njihove primjene u Hrvatskoj i Habsburškoj Monarhiji. U svojim objavljenim (i neobjavljenim) tekstovima javno je i argumentirano zagovarao one ideje i znanja za koje je držao da se uz određenu prilagodbu mogu primijeniti u njegovoj domovini. Na taj je način uvelike pridonio transferu ideja i znanja iz drugih europskih zemalja i njihovoj recepciji u Hrvatskoj na političkom i pedagoškom polju u 19. stoljeću.

\section{Summary}

\section{MIJAT STOJANOVIĆ - FROM A NAUGHTY PUPIL TO A PROMINENT EDUCATIONIST AND POPULAR WRITER OF THE $19^{\text {TH }}$ CENTURY}

This paper presents the public work of Mijat Stojanović (1818-1881), one of the most prominent Croatian popular writers, teachers and educationists of the $19^{\text {th }}$ century. During his two-year formal education, he evolved from one of the poorest pupils to the best pupil in his class. Subsequently, thanks to his extraordinary self-discipline, motivation and self-education, he gradually progressed from auxiliary teacher to district school inspector. Very early on, he recognised the major role of the teacher in society and directed his own life-long learning towards professional development and acquisition of more knowledge from foreign and domestic literature. He presented the knowledge not only in the classroom and at teacher meetings, but also in many articles published in political papers and professional magazines. He wrote about the role of school in society, dwelt upon various educational issues, gave practical advice on the economy and politics. He was most active in political life during the revolutionary years 1848-1849 when he was elected Member of Croatian Parliament. He wrote a larger number of popular books, school textbooks and translated a number of educational handbooks written by prominent foreign educationists. Through his public activities he considerably contributed to the transfer of ideas and knowledge from other European countries and their reception in Croatia in the political and educational fields.

Key words: Mijat Stojanović, history of schooling, transfer of ideas and knowledge, educational activity, nonfiction writing, $19^{\text {th }}$ century, Croatia

\section{Kontakt:}

Dr. sc. Vlasta Švoger

Hrvatski institut za povijest, Opatička 10, 10000 Zagreb

e-mail: vsvoger@isp.hr 